\title{
Kunnen we nog zonder e-learning in het moderne medisch onderwijs?
}

\author{
E.A. Dubois, A.W. Riedstra, A.B.D. van Doorn, namens de Werkgroep COO van de NVMO
}

\section{Inleiding}

In het voorjaar van 2002 bestond de Werkgroep voor Computerondersteund Onderwijs (COO) van de Nederlandse Vereniging voor Medisch Onderwijs (NVMO) 10 jaar. Om dit te vieren werd het initiatief genomen tot een Lagerhuisdebat over e-learning in het medisch onderwijs tijdens het Gezond Onderwijs Congres (GOC) in Egmond aan Zee in november 2002. Het onderwerp e-learning lag voor de hand, omdat het een hot item is en een belangrijke ontwikkeling die iedereen aangaat die bij onderwijs betrokken is.

Als inleiding op het debat werd kort een overzicht gegeven van verschillende termen en begrippen aangaande computers in het onderwijs. Vervolgens werd onder leiding van oudNVMO-voorzitter Lennart Bouwman geanimeerd gediscussieerd over zes stellingen met betrekking tot het gebruik van computers in het medisch onderwijs. In deze bijdrage wordt beknopt verslag gedaan van het debat.

\section{De Werkgroep voor Computeronder- steund Onderwijs}

Sinds vele jaren wordt er aan de diverse medische faculteiten in Nederland computerondersteund onderwijs (COO) ontwikkeld. Om deze ontwikkelingen enigszins te stroomlijnen is in 1992 vanuit de Nederlandse Vereniging voor Medisch Onderwijs (NVMO) een werkgroep opgericht. In deze werkgroep zijn COO-medewerkers van de meeste medische faculteiten vertegenwoordigd. De belangrijkste doelstelling van de werkgroep is het leggen en onderhouden van contacten tussen COO-ontwikkelaars. Op werkgroepbijeenkomsten worden ervaringen uitgewisseld en worden leden geïnformeerd over nieuwe ontwikkelingen. Op de website van de werkgroep wordt een overzicht van het in Nederland en Vlaanderen ontwikkelde COO-materiaal bijgehouden. De werkgroep komt zo'n zes keer per jaar bijeen om aandacht te besteden aan nieuwe ontwikkelingen en programma's. Tevens wordt regelmatig een instantie binnen of buiten de universitaire gemeenschap bezocht om op de hoogte te blijven van nieuwe ontwikkelingen op het gebied van computerondersteund onderwijs of gerelateerde vakgebieden. Om internationale ontwikkelingen in de gaten te houden, wordt elke twee jaar een studiereis naar het buitenland georganiseerd, waarbij verschillende universiteiten worden bezocht.

\section{Het Lagerhuisdebat}

De deelnemers aan het Lagerhuisdebat hebben een evaluatieformulier ingevuld, waarin hun mening inzake zes stellingen met betrekking tot het gebruik van computers in het medisch onderwijs werd gevraagd (zie tabel 1). Belangrijke kwesties als de toenemende aantallen studenten, de computerinfrastructuur, de samenwerking met docenten en de waardering voor COO kwamen aan de orde. Na afloop van het debat zijn de resultaten van de peilingen verwerkt en deze worden hier gepresenteerd. 
Tabel 1. De zes stellingen over computers in het medisch onderwijs, waarover gediscussieerd werd in het Lagerhuisdebat tijdens het GOC in Egmond aan Zee op 15 november 2002.

1. Vanwege de toenemende aantallen studenten geneeskunde is e-learning absoluut noodzakelijk.

2. De huidige ICT-infrastructuur biedt voldoende mogelijkheden voor e-learning.

3. Docenten zonder verstand van computers zijn niet geschikt voor de ontwikkeling van e-learning.

4. Een ELO is onmisbaar in het medisch onderwijs.

5. Goed COO kan docenten vervangen.

6 De ontwikkeling van COO-lessen moet gelijkwaardig gesteld worden aan het publiceren van wetenschappelijke artikelen.

\section{De resultaten van het Lagerhuisdebat}

Figuur 1 toont een overzicht van de meningen over de stellingen voor en na de discussie. Bij alle stellingen, op stelling zes na, is de groep tegenstanders aan het eind van de discussie het grootst en groeit de oneens-groep tijdens het debat over de betreffende stellingen. Verder kan vastgesteld worden dat het aantal deelnemers zonder mening tijdens iedere discussie afneemt. Er kan dus geconcludeerd worden dat de discussies hebben geleid tot de vorming van een mening.

\section{Toekomst voor ICT in het medisch onderwijs}

Tijdens het Lagerhuisdebat kwamen een aantal ideeën en suggesties naar voren. Om het onderwijs voor de toenemende aantallen studenten ook in de toekomst mogelijk te maken, zou e-learning een mooie oplossing zijn. De meeste medische faculteiten hebben al een elektronische leeromgeving, maar er moet nog heel wat geregeld worden om de integratie van ICT in het medisch onderwijs geheel te doen slagen. Zo is een goede technische infrastructuur met bijbehorende organisatie een belangrijke voorwaarde.

De algemene tendens van het debat laat zien dat e-learning in de toekomst grote mogelijkheden lijkt te hebben. Ook de Nederlandse overheid lijkt daarvan overtuigd te zijn, gezien het actieve beleid om het rendement van ICT in het onderwijs te bevorderen. Maar, om e-learning in het medisch onderwijs te laten slagen, is een betere samenwerking tussen verschillende groepen (docenten, computertechnici, managers, ontwikkelaars en studenten) erg belangrijk. Velen zien een betere organisatie van en aandacht voor ICT, COO en onderwijs zelfs als voorwaarde voor een complete integratie in het moderne medisch onderwijs. Scholing van docenten op het gebied van digitale didactiek heeft hierbij prioriteit.

Voor de Werkgroep COO lijkt een duidelijke taak weggelegd om de mogelijkheden van e-learning meer onder de aandacht te brengen. Om de kwaliteit van COO-programma's te waarborgen zou een reviewcomité opgericht kunnen worden.

Tot slot is de vorm van het Lagerhuisdebat op het GOC 2002 buitengewoon goed bevallen bij de deelnemers. In zo'n debat kan iedereen zijn/haar mening geven, maar wordt er wel volgens een vaste structuur gediscussieerd, zodat de discussie niet uit de hand loopt. Er kan overwogen worden een Lagerhuisdebat als nieuwe sessievorm op het GOC in te voeren in de toekomst.

Een uitgebreid verslag van het Lagerhuisdebat met beschrijvingen van de discussies en alle argumenten kunt $\mathrm{u}$ vinden op de internetsite van de NVMO (http:// www.nvmo.nl) onder werkgroepen, ComputerOndersteund Onderwijs. Hier staat ook meer informatie over de werkgroep 

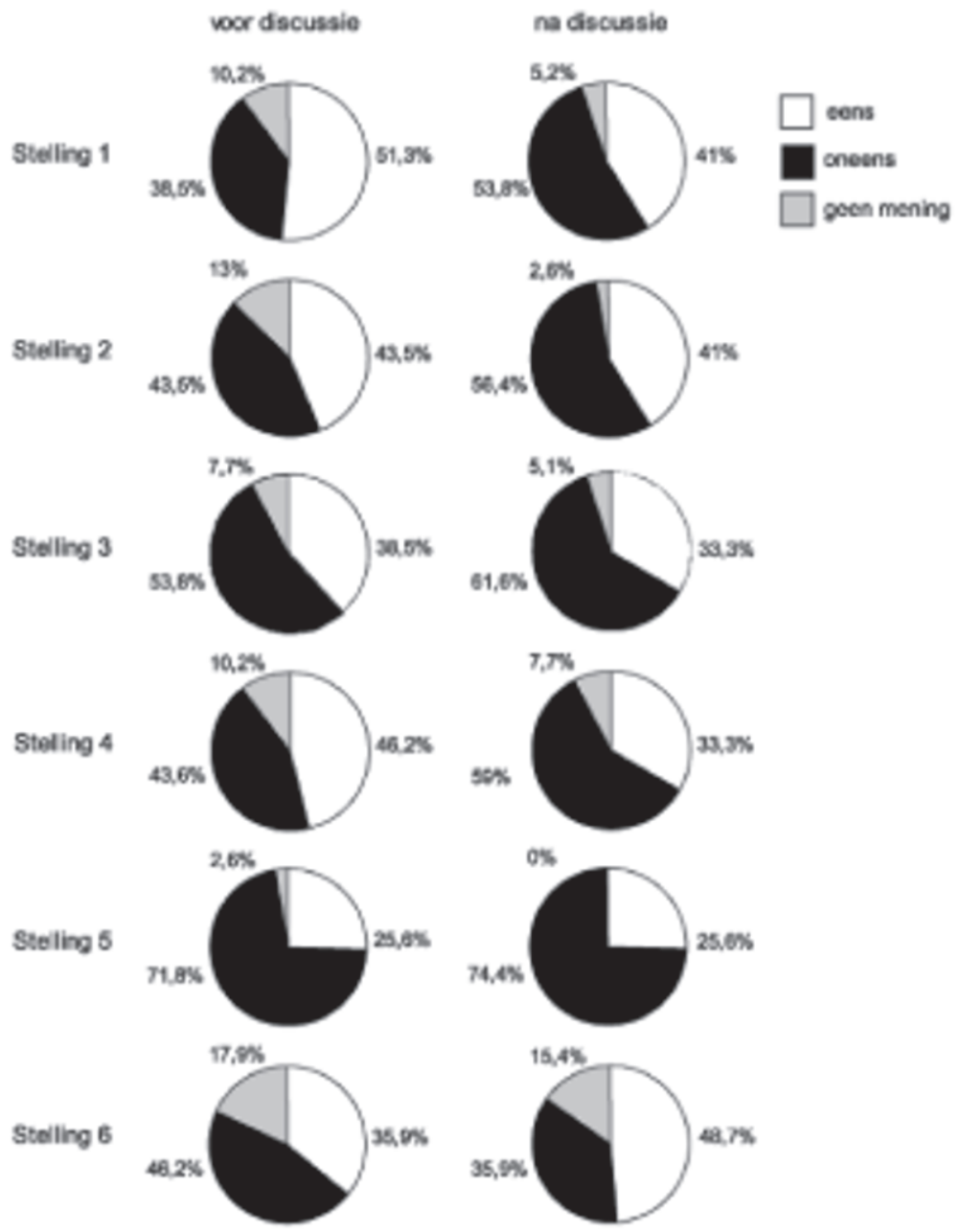

Figuur 1. Percentages van de deelnemers aan het Lagerhuisdebat, die het eens (wit) of oneens (zwart) waren met een stelling of die geen menig (grijs) hadden. De linkerrij toont de percentages van de peiling voor de discussie; de rechterrij na afloop. De stellingen staan weergegeven in tabel 1.

en een overzicht van alle COO-lessen in Nederland en Vlaanderen.

\section{De auteurs:}

Dr. E. A. Dubois, onderwijsmedewerker, project coördinator Teaching Resource Centre Pharmacology, Onderwijscentrum Inwendige Geneeskunde, Leids Universitair Medisch Centrum.

Drs. A. W. Riedstra, coördinator computerondersteund onderwijs, Onderwijscentrum Inwendige Geneeskunde, Leids Universitair Medisch Centrum.
A.B.D. van Doorn, voorzitter Werkgroep Computerondersteund Onderwijs van de NVMO, Disciplinegroep Klinische Farmacologie, Faculteit der Medische Wetenschappen, Rijksuniversiteit Groningen.

Namens de Werkgroep COO van de NVMO.

\section{Correspondentieadres:}

Dr. E. A. Dubois, LUMC, Onderwijscentrum IG, C5-Q, Postbus 9600, 2300 RC Leiden, tel: 071-5262322, fax:071-5266857,E.A.Dubois@lumc.nl. 